\title{
Correction to: Perspectives of the World's Energy System
}

\author{
José Goldemberg ${ }^{1}$
}

Published online: 13 August 2018

(C) Escola Politécnica - Universidade de São Paulo 2018

\section{Correction to: Polytechnica}

$$
\text { https://doi.org/10.1007/s41050-018-0003-3 }
$$

On p. 5 of the published article, in the last paragraph and in the Fig. 9 caption, " $9000 \mathrm{kWh} / \mathrm{L}$ " should be " $9 \mathrm{kWh} / \mathrm{L}$ ". An additional correction is needed in the Fig. 9 caption, wherein "5000 kWh/L" should be " $5 \mathrm{kWh} / \mathrm{L}$ ".

The online version of the original article can be found at https://doi.org/ 10.1007/s41050-018-0003-3

\footnotetext{
José Goldemberg

goldemb@iee.usp.br

1 Instituto de Energia e Ambiente, University of São Paulo, Av. Prof. Luciano Gualberto, 1289, Cidade Universitária, São

Paulo 05508-010, Brazil
} 